\title{
GROWTH OF YERSINIA PSEUDOTUBERCULOSIS IN MOUSE SPLEEN DESPITE LOSS OF A VIRULENCE PLASMID OF MOL. WT $47 \times 10^{6}$
}

\author{
M. Simonet, D. MaZigh*, P. BerChe \\ Laboratoire de Microbiologie, Faculté de Médecine Necker-Enfants Malades, 75730 \\ Paris and *Unité d'Ecologie Bactérienne, Centre National des Yersinia, Institut \\ Pasteur, 75724 Paris Cedex 15, France
}

\begin{abstract}
SUMmaRY. A highly virulent strain of Yersinia pseudotuberculosis (LD50 c. $10^{2}$ bacteria/mouse) harboured two plasmids with mol. wt of $47 \times 10^{6}$ and $61 \times 10^{6}$. The role of these plasmids in virulence was studied in mice with derived strains cured of plasmids. It was confirmed that the plasmid of mol. wt $47 \times 10^{6}$ played a major function in virulence. This was shown both by the increase of the LD50 and the lower rate of multiplication in the spleen obtained with strains cured of the plasmid of mol. wt $47 \times 10^{6}$. The plasmid of mol. wt $61 \times 10^{6}$ did not play any role in virulence. This work also demonstrates that the strain cured of the plasmid of mol. wt $47 \times 10^{6}$ and the plasmid-free strain were able to multiply in the spleens of infected mice during a 7-day period. This suggests that virulence factors not associated with plasmids are also responsible for the bacterial growth in tissues in vivo.
\end{abstract}

\section{INTRODUCTION}

Yersinia pseudotuberculosis causes epizootic outbreaks with various patterns of disease in birds and in domestic and wild mammals. It may also cause disease in man (Mollaret, 1965). Several authors have reported that plasmids with mol. wt between $42 \times 10^{6}$ and $47 \times 10^{6}$ are associated with the virulence of the various species of Yersinia, i.e., Y. enterocolitica, Y. pestis and Y.pseudotuberculosis (Gemski, Lazere and Casey, 1980a; Gemski et al., 1980b; Ben-Gurion and Shafferman, 1981; Portnoy and Falkow, 1981). It has been shown that the presence of these plasmids is related to the synthesis of $\mathrm{V}$ and $\mathrm{W}$ antigens which appear to be essential for the virulence of the genus Yersinia (Brubaker, 1972). Pathogenicity of Y. pseudotuberculosis has been studied by inducing keratoconjunctivitis in the guinea pig (Gemski et al., 1980b; Mäki et al., 1983) and by assessing mortality in the mouse (Ben-Gurion and Shafferman, 1981; Bölin, Norlander and Wolf-Watz, 1982). The purpose of this work was to study the virulence of $Y$. pseudotuberculosis strains with or without a plasmid of mol. wt $47 \times 10^{6}$ by following the kinetics of bacterial growth in the spleens and survival of infected mice. 


\section{MATERIALS AND METHODS}

Bacterial strains. The strain of $Y$. pseudotuberculosis used in these experiments was isolated from a blood culture from a patient with fatal septicaemia (Simonet, Berche and Mazigh, 1983); it was Y. pst. 2637 (Collection of the Centre National des Yersinia, Institut Pasteur, Paris). Bacteria were grown in trypto-casein soy broth (TCSB) or agar (TCSA). Stock cultures were kept at $-70^{\circ} \mathrm{C}$ until required.

A strain of $Y$. pestis (Y.p. EV 76) harbouring three plasmids of mol. wt $6 \times 10^{6}, 47 \times 10^{6}$ and $61 \times 10^{6}$ (Portnoy and Falkow, 1981), and a strain of Y. enterocolitica 09 (Y.e. IP 383) harbouring a plasmid of mol. wt $47 \times 10^{6}$ (Mazigh et al., 1983) were used as controls.

Screening and cure of plasmids. Plasmid DNA was isolated from bacteria grown at $25^{\circ} \mathrm{C}$ in peptone water and analysed by electrophoresis in $0.7 \%$ agarose gels according to the method of Portnoy, Moseley and Falkow (1981). The gel was stained by ethidium bromide and DNA was visualised in UV light. The mol. wt of plasmids extracted from $Y$. pst. 2637 and its derivative $Y$. pst. 2637a were estimated by comparison of their distances of migration with those of plasmids of known mol. wt extracted from reference strains Y.p. EV76 and Y.e. IP383. Loss of plasmids was obtained by five subcultures of $Y$. pseudotuberculosis strains at $37^{\circ} \mathrm{C}$ or $43^{\circ} \mathrm{C}$ in TCSB, according to classical methods for temperature-induced cures (Cuzin and Jacob, 1967; Vesikari et al., 1981).

Infection of mice. Specific pathogen-free ICR female Swiss mice (Iffa Credo, France), 6 weeks old, were given intravenous (IV) injections of $0.5 \mathrm{ml}$ of various dilutions of an overnight bacterial culture grown at $25^{\circ} \mathrm{C}$ in TCSB. The LD50 was determined in groups of five mice by the probit method. Growth of bacteria in the spleen was followed in relation to time after the IV injection. Groups of four animals were killed by cervical dislocation and the organs were removed aseptically and homogenised separately in $9 \mathrm{ml}$ of sterile saline; $0 \cdot 1-\mathrm{ml}$ volumes of serial ten-fold dilutions in saline were spread on TCSA and colonies were counted after incubation for $48 \mathrm{~h}$ at $25^{\circ} \mathrm{C}$.

\section{RESULTS}

Strain $Y$. pst. 2637 was subcultured five times in TCSB at $37^{\circ} \mathrm{C}$ and a derivative, designated $Y$. pst. 2637a, was obtained after screening five colonies for the presence of plasmids. This derivative was then subcultured five times at $43^{\circ} \mathrm{C}$, which allowed us to isolate, after the same screening, a second derivative designated $Y$. pst. 2637b. The agarose gel electrophoretic profiles of plasmid DNA extracted from the parent $Y$. pst. 2637 strain and the two temperature-induced derivatives are illustrated in fig. 1 . The parent strain harboured two plasmids which migrated like the plasmid DNA of the reference strains used as controls, Y.p. EV76 $\left(6 \times 10^{6}, 47 \times 10^{6}\right.$ and $61 \times 10^{6}$ mol. wt $)$ and Y.e. IP383 $\left(47 \times 10^{6} \mathrm{~mol}\right.$. wt). The derivative Y. pst. 2637 a harboured only the plasmid of mol. wt $61 \times 10^{6}$, whereas the derivative $Y$. pst. $2637 \mathrm{~b}$ had no plasmid detectable by this electrophoretic method (fig. 1).

The virulence of the parent strain and its two derivatives was studied by determining their LD50. The parent strain ( $Y$. pst. 2637) was highly virulent in mice; the LD50 after IV injection was $c .10^{2}$ bacteria/mouse. Loss of the plasmid of mol. wt $47 \times 10^{6}$ resulted in a $10^{4}$ increase of the LD50. The LD50 of the strains Y. pst. $2637 \mathrm{a}$ and $2637 \mathrm{~b}$ were assessed to be $c .1-2 \times 10^{6}$ bacteria/mouse.

The bacterial growth in the spleens of mice was measured in mice infected by the parent strain and its two derivatives (dose $5 \times 10^{3}$ bacteria IV). The data obtained during a 14-day period are shown in fig. 2 . The parent strain rapidly proliferated in the spleen during the first 3 days with early formation of abcesses. After the third day, mice began to die and no mice survived after day 6 . In contrast, after inoculation of either 


\section{Mol. wt}

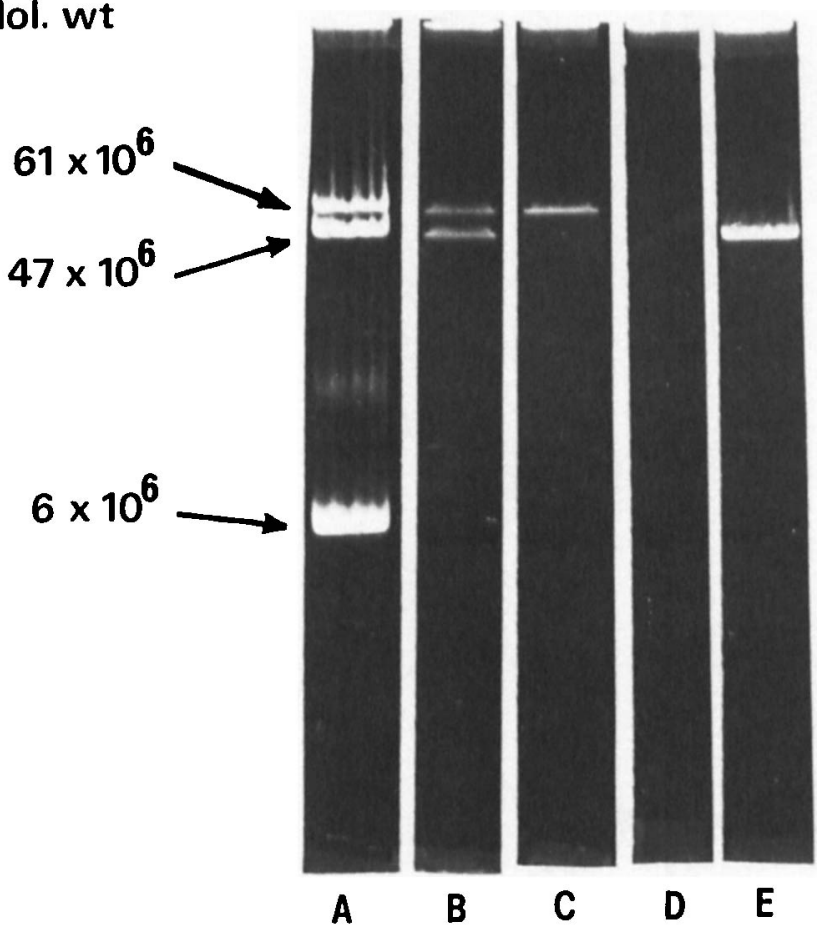

Fig. 1.-Agarose gel electrophoresis of plasmids extracted from various strains of Yersinia. The tracks contain DNA from strains Y.p. EV 76(A), Y. pst. 2637 (B), Y.pst. 2637a (C), Y.pst. 2637b(D), Y.e. IP $383(\mathrm{E})$.

strain $Y$.pst. 2637a or strain $Y$.pst. 2637 b, bacteria grew more slowly in the spleen than did those of the parent strain. This growth reached a peak by day 7 and then the number of bacteria steadily declined until they were almost completely eliminated by day 21 (data not shown). Electrophoretic analysis of lysates of 10 colonies isolated from the spleen on day 7 of infection with $Y$.pst. 2637a and $Y$.pst. 2637b, showed the absence of the plasmid of mol. wt $47 \times 10^{6}$ in these two derivatives, whereas $Y$. pst. 2637a still harboured the plasmid of mol. wt $61 \times 10^{6}$.

\section{Discussion}

The parent strain of $Y$.pseudotuberculosis used in this study harbours two plasmids (fig. 1): (i) a plasmid of mol. wt $47 \times 10^{6}$ as previously described in virulent strains of $Y$. pseudotuberculosis (Gemski et al., 1980b; Ben-Gurion and Shafferman, 1981); and (ii) a plasmid of mol. wt $61 \times 10^{6}$, so far never described in $Y$. pseudotuberculosis, which migrated similarly to the cryptic plasmid of mol. wt $61 \times 10^{6}$ of $Y$. pestis (Ferber and Brubaker, 1981; Portnoy and Falkow, 1981). This strain was highly virulent in mice (LD50 $=c .10^{2}$ bacteria/mouse) and quickly invaded the spleen (fig. 2).

The loss of the plasmid of mol. wt $47 \times 10^{6}$ in the two derived strains of $Y$. pseudotuberculosis resulted in loss of virulence (LD50 $=(1-2) \times 10^{6}$ bacteria/ mouse). This confirms the major role of the plasmid of mol. wt $47 \times 10^{6}$ in virulence of 


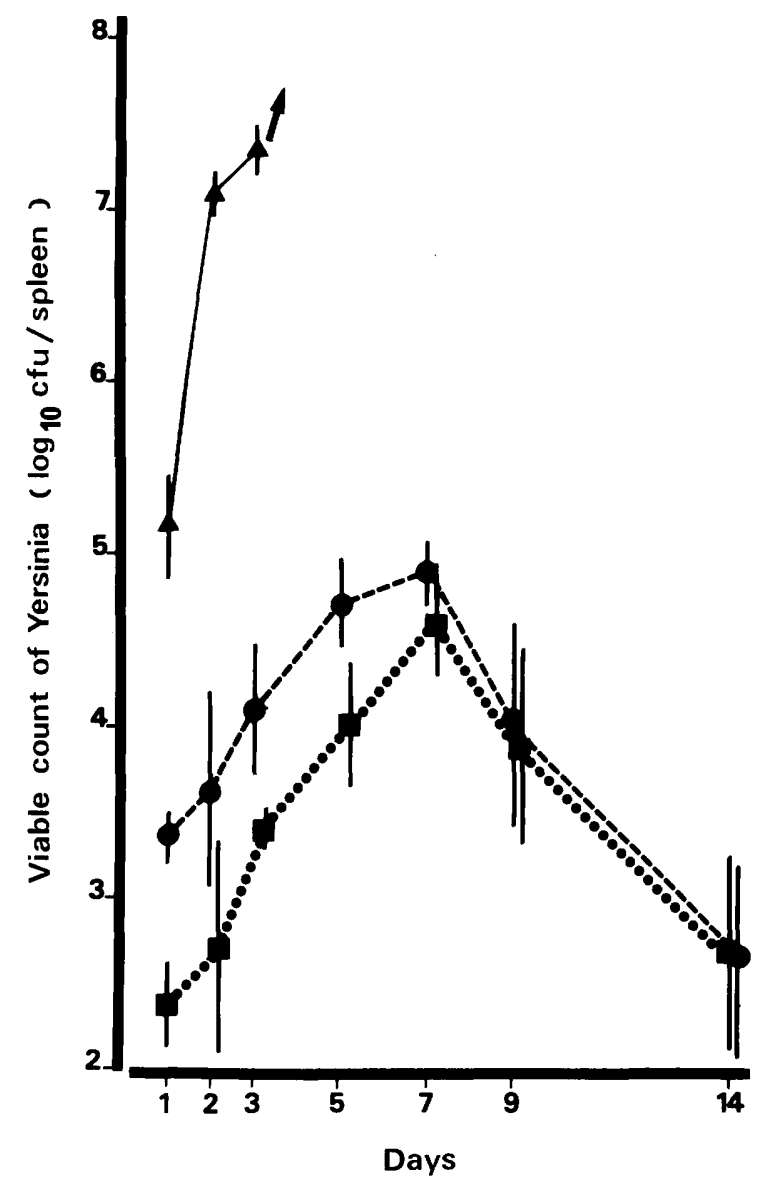

FIG. 2.-Bacterial growth of $Y$. pseudotuberculosis in the spleens of mice given IV injections of $5 \times 10^{3}$ bacteria prepared from the parent strain $Y$. pst. $2637(\Lambda-\Lambda)$ or its two derivatives $Y$. pst. 2637 a $(\square \cdot \cdots)$ and $Y$. pst. $2637 \mathrm{~b}(\bullet \cdots \bullet)$. Each point is the mean value of groups of 4 mice \pm SD.

yersiniae (Gemski et al., 1980 $a$ and $b$; Ben-Gurion and Shafferman, 1981; Portnoy and Falkow, 1981). However, it is shown in fig. 2 that the two derived strains, harbouring or not the plasmid of mol. wt $61 \times 10^{6}$, were still capable of growing in the spleen during a 7-day period. These data suggest that the plasmid of mol. wt $61 \times 10^{6}$ is probably not involved in virulence and its role remains unknown. Moreover, some strains of $Y$. enterocolitica that lack the virulence-associated plasmid are rapidly eliminated from organs of infected mice without any growth (Berche and Carter, 1982; Mazigh et al., 1983) and our data with $Y$. pst. 2637 and its derivatives suggest that factors not associated with plasmids are responsible for the bacterial growth in organs observed when the plasmid of mol. wt $47 \times 10^{6}$ was absent.

\section{REFERENCES}

Ben-Gurion R, Shafferman A, 1981 Essential virulence determinants of different Yersinia species are carried on a common plasmid. Plasmid 5:183-187. 
Berche P A, Carter P B 1982 Calcium requirement and virulence of Yersinia enterocolitica. Journal of Medical Microbiology 15:277-284.

Bölin I, Norlander L, Wolf-Watz H 1982 Temperature-inducible outer membrane protein of Yersinia pseudotuberculosis and Yersinia enterocolitica is associated with the virulence plasmid. Infection and Immunity 37:506-512.

Brubaker R R 1972 The genus Yersinia: biochemistry and genetics of virulence. Current Topics in Microbiology and Immunology 57:111-158.

Cuzin F, Jacob F 1967 Mutations de l'épisome F d'Escherichia coli K.12. 2. Mutants à réplication thermosensible. Annales de l'Institut Pasteur 112:397-418.

Ferber D M, Brubaker R R 1981 Plasmids in Yersinia pestis. Infection and Immunity 31:839-841.

Gemski P, Lazere J R, Casey T 1980a Plasmid associated with pathogenicity and calcium dependency of Yersinia enterocolitica. Infection and Immunity 27:682-685.

Gemski P, Lazere J R, Casey T, Wohlhieter J A 1980b Presence of a virulence-associated plasmid in Yersinia pseudotuberculosis. Infection and Immunity 28:1044-1047.

Mäki M, Vesikari T, Rantala I, Sundqvist C, Grönroos P 1983 Pathogenicity of 42-44 Mdal plasmid positive and negative Yersinia pseudotuberculosis 1 and Yersinia enterocolitica 0:8 and 0:9 studied in the guinea pig eye model (Serény test). Acta Pathologica Microbiologica Scandinavica, Section B, 91:241-244.

Mazigh D, Chalvignac M A, Alonso J M, Mollaret H H 1983 Déterminisme génétique de la virulence de Yersinia enterocolitica et de l'immunogénicité croisée contre Yersinia pestis. In Les bacilles à Gram négatif d'intérêt médical et en Santé Publique: Taxonomie-Identification-Applications, les Colloques de l'INSERM. INSERM 114:517-535.

Mollaret H H 1965 Les formes cliniques de l'infection humaine à bacille de Malassez et Vignal. Pathologie et Biologie 13:554-566.

Portnoy D A, Falkow S 1981 Virulence-associated plasmids from Yersinia enterocolitica and Yersinia pestis. Journal of Bacteriology 148:877-883.

Portnoy D A, Moseley S L, Falkow S 1981 Characterization of plasmids and plasmid-associated determinants of Yersinia enterocolitica pathogenesis. Infection and Immunity 31:775-782.

Simonet M, Berche P, Mazigh D 1983 Une septicémie due à une souche hautement virulente de Yersinia pseudotuberculosis. Médecine et Maladies Infectieuses 13:767-771.

Vesikari T, Nurmi T, Mäki M, Skurnik M, Sundqvist C, Granfors K, Grönroos P 1981 Plasmids in Yersinia enterocolitica serotypes $0: 3$ and $0: 9$ : correlation with epithelial cell adherence in vitro. Infection and Immunity 33:870-876. 